\title{
Educar Mais
}

\section{Memes de internet e educação: aproximando as redes sociais à sala de aula}

\author{
Internet memes and education: approaching social networks to the \\ classroom
}

Internet memes y educación: acercando las redes sociales al aula

Paula Fernanda Rodrigues Brum¹; Juliana Brandão Machado²

\begin{abstract}
RESUMO
Este artigo apresenta o recorte de uma pesquisa-intervenção realizada com alunos de uma turma de $9^{\circ}$ ano do Ensino Fundamental de uma escola pública localizada em um município ao sul do Rio Grande do Sul, acerca da aproximação das redes sociais com a sala de aula. $O$ objetivo foi analisar a incorporação das tecnologias digitais no processo de escrita colaborativa na disciplina de Produção Textual, procurando avaliar se tal intervenção colaborou com o processo de ensino e de aprendizagem através da utilização das tecnologias digitais. Para desenvolver a pesquisa propomos uma atividade em que os alunos pudessem interagir com seus pares, procurando desta forma trabalhar na perspectiva da colaboratividade. A atividade desenvolveu-se na disciplina de Produção Textual. A proposta teve como referência um meme, que em sua maioria foram produzidos pelos alunos. A partir do estudo conseguimos perceber que a utilização dos dispositivos móveis proporcionou maior aproximação dos alunos com a disciplina de Produção Textual, bem como desenvolveu a criatividade e colaboração dos sujeitos pesquisados.
\end{abstract}

Palavras-chave: Educação; Tecnologias Digitais; Memes de Internet.

\begin{abstract}
This article presents an excerpt from an intervention research carried out with students from a 9th grade group of elementary school in a public school located in a city in the south of Rio Grande do Sul, about the approximation of social networks with the classroom. The objective was to analyze the incorporation of digital technologies in the process of collaborative writing in the discipline of Textual Production, seeking to evaluate whether such intervention collaborated with the teaching and learning process through the use of digital technologies. To develop the research, we propose an activity in which students could interact with their peers, thus seeking to work from the perspective of collaboration. The activity was developed in the discipline of Textual Production. The proposal was based on a meme, which was mostly produced by the students. From the study, we realized that the use of mobile devices provided students with a closer relationship with the discipline of Textual Production, as well as developed the creativity and collaboration of the subjects surveyed.
\end{abstract}

Keywords: Education; Digital Technologies; Internet Memes.

\footnotetext{
${ }^{1}$ Mestra em Educação, Especialista em Mídias na Educação e Licenciada em Letras. Professora da Rede Municipal de Ensino de Herval, Herval/RS - Brasil. E-mail: professorapaulafernanda@gmail.com

2 Doutora em Educação, Professora Adjunta da Universidade Federal do Pampa (UNIPAMPA) e docente do Programa da Pós-graduação em Educação - PPGEdu/UNIPAMPA, Jaguarão/RS - Brasil. E-mail: julianamachado@unipampa.edu.br
} 


\section{RESUMEN}

Este artículo presenta un extracto de una investigación de intervención realizada con estudiantes de un grupo de $9^{\circ}$ grado de la escuela primaria en una escuela pública ubicada en una ciudad del sur de Rio Grande do Sul, sobre la aproximación de las redes sociales con el aula. El objetivo fue analizar la incorporación de tecnologías digitales en el proceso de escritura colaborativa en la disciplina de Producción Textual, buscando evaluar si dicha intervención colaboró con el proceso de enseñanza y aprendizaje a través del uso de tecnologías digitales. Para desarrollar la investigación, proponemos una actividad en la que los estudiantes puedan interactuar con sus compañeros, buscando así trabajar desde la perspectiva de la colaboración. La actividad se desarrolló en la disciplina de Producción Textual. La propuesta se basó en un meme, que en su mayoría fue producido por los estudiantes. A partir del estudio, nos dimos cuenta de que el uso de dispositivos móviles proporcionó a los estudiantes una relación más cercana con la disciplina de Producción Textual, así como desarrolló la creatividad y la colaboración de los sujetos encuestados.

Palabras clave: Educación; Tecnologías Digitales; Memes de Internet.

\section{INTRODUÇÃO}

O contexto contemporâneo tem destacado o distanciamento da escola, enquanto instituição formal de ensino, e as demais esferas da sociedade, especialmente na relação com as tecnologias digitais. Desta forma, é urgente pensar outras metodologias de ensino, a fim de atender às mudanças que vêm ocorrendo constantemente na evolução humana e, sobretudo, para que a escola não fique avessa a essas transformações. Dialogando com Sibilia (2012), compartilhamos do seu pensamento quando nos diz que

onde imperavam as normas ríspidas do confinamento para educar cidadãos oitocentistas com a força do sangue, do suor e da palavra, agora se estendem as tramas atraentes da conexão, que opera de outro modo e com objetivos diferentes: enfeitiçando os consumidores contemporâneos com suas incontáveis delícias transmidiáticas. (SIBILIA, 2012, p.174).

Atualmente, quem chega à escola ainda encontra, na maioria dos contextos, uma instituição organizada na forma tradicional do ensino, com os alunos dispostos enfileirados e o docente como o único detentor do conhecimento. Parece, nesta perspectiva, que as escolas, como um todo, ainda não conseguem dinamizar o ensino, integrando-o com o tempo em que se vive hoje. Neste sentido, a pesquisa teve como tema o uso das tecnologias digitais no processo de ensino e de aprendizagem, a fim de que se pudesse aproximar a escola dos sujeitos que nela adentram atualmente, tendo em vista que são sujeitos ativos e conectados à sociedade do conhecimento. A necessidade de que se utilizem metodologias que estejam adequadas ao tempo em que vivemos também justificou o estudo. Assim, o objetivo principal da pesquisa pautou-se em observar se a utilização das tecnologias digitais no processo educacional poderia contribuir com o aprendizado dos educandos.

É relevante refletir e (re)pensar sobre as práticas docentes buscando novas metodologias que atendam a essa demanda, tendo em vista que "novas possibilidades de comunicação móvel são trazidas cotidianamente" (PRETTO, 1996, p. 106). Neste sentido, é importante defender que a escola também se constitua num espaço que potencialize o uso das tecnologias digitais no processo de ensino, colaborando para que o educando utilize a informação que hoje tem disponível - na palma da mão - no processo de aprendizagem. Segundo Sibilia (2012) 
enquanto os alunos de hoje vivem fundidos em diversos dispositivos eletrônicos e digitais, a escola continua obstinadamente arraigada em seus métodos e linguagens analógicos; isso talvez explique por que os dois não se entendem e as coisas já não funcionam como se esperaria. (SIBILIA, 2012, p.181).

Desta forma, se os alunos vivem hoje fundidos aos seus dispositivos móveis, defendemos que estes artefatos tecnológicos podem ser utilizados no processo de ensino e de aprendizagem.

Se tivermos um olhar mais atento e considerando que as tecnologias digitais ainda não são incorporadas em grande parte das práticas pedagógicas, perceberemos que os alunos, grosso modo, tornam-se excluídos, à margem de uma aprendizagem fundamentada no princípio de uma educação inovadora, dinâmica e, sobretudo, mais atrativa. Destarte, é relevante que os discentes estejam inseridos e incluídos em um processo de ensino contemporâneo. Neste sentido, Costa (2006, p. 2) nos diz que "estar inserido digitalmente hoje é condição fundamental para a existência de cidadãos plenos na interação com esse mundo da informação e comunicação".

As metodologias de ensino utilizadas em outros tempos provavelmente hoje já não dão mais conta do que se transformou o processo de aquisição do conhecimento e para atender a demanda de alunos que chegam às nossas salas de aula. Percebe-se que hoje uma aula ministrada somente de maneira tradicional já não atrai mais tanto a atenção dos alunos, que tentam muitas vezes burlar as proibições que lhes são impostas, principalmente em relação ao contato com seus dispositivos móveis na escola. Conforme Lévy (1998)

é certo que a escola é uma instituição que há cinco mil anos se baseia no falar/ditar do mestre, na escrita manuscrita do aluno e, há quatro séculos, em uso moderado da impressão. Uma verdadeira integração da informática supõe, portanto, o abandono de um hábito antropológico mais que milenar [...]. (LÉVY, 1998, p.8).

Embora inserir-se no contexto tecnológico possa ser um processo lento, principalmente para os docentes, o professor deste tempo necessita desenvolver outras competências, para atuar também como um mediador do conhecimento, permitindo que os alunos explorem o universo conectado no espaço escolar, porque é dessa maneira que estão vivendo.

É perceptível que ensinar e aprender hoje exigem muito mais flexibilidade do que em outros tempos vivenciados. Na visão de Santos (2014, p.40) "o professor precisará se dar conta do espírito do nosso tempo para nele atuar. Ele precisará ir além da inclusão digital, entendida como habilidade no uso do computador". Entende-se que isso não significa que a escola não precisará mais do professor como agente principal e transformador do ensino, mas sim que o papel do professor passa por modificações, ou seja, agora o docente também auxilia o aluno na contextualização de todos os dados que ele recolhe na rede. Conforme Pretto (2008)

no campo da educação, formulamos a ideia de que a incorporação dessas tecnologias não pode se dar meramente como ferramentas adicionais, complementares, como meras animadoras dos tradicionais processos de ensinar e de aprender. As tecnologias necessitam ser compreendidas como elementos fundantes das transformações que estamos vivendo. (PRETTO, 2008, p. 80).

Visto dessa forma, entende-se que o educador que leciona hoje, vivendo a cibercultura, necessita ser articulador e principalmente parceiro dos seus alunos no processo de ensino e de aprendizagem, precisa preocupar-se também com o aprender a aprender, possibilitando novos caminhos para si e para seus alunos. Porém, além disso, o aluno também precisará abandonar o papel passivo, onde escuta, lê, decora e repete, e passar a ser criativo e atuante para produzir o seu conhecimento. 
Professores e alunos devem buscar juntos o conhecimento. O desafio é mudar a maneira de ensinar para ir por outros caminhos que também levem ao aprender. Professor e alunos devem estar em constante processo de aprendizagem.

Nesta perspectiva, mais do que nunca, a escola, para que tenha êxito em cumprir sua função na sociedade contemporânea, precisa também preocupar-se e adequar-se às novas metodologias de ensino, tendo em vista que os alunos que adentram à escola cotidianamente estão consideravelmente carregados de informações, muitas destas envolvendo o uso das tecnologias digitais diariamente.

Desta forma, este artigo irá apresentar um recorte de uma pesquisa-intervenção realizada com alunos do 90 ano do Ensino Fundamental de uma escola da rede pública municipal, de um município localizado ao Sul do Brasil, que teve como objetivo analisar a incorporação das tecnologias digitais no processo de escrita colaborativa na disciplina de Produção Textual, procurando avaliar se tal intervenção colaborou com o processo de ensino e de aprendizagem através da utilização das tecnologias digitais. Atribuímos a nomeação "pesquisa-intervenção" ao estudo para destacar a característica de uma pesquisa aplicada em uma realidade educacional que mantém, ao mesmo tempo, seu caráter investigativo.

Cabe destacar, ainda, que tal experiência aqui relatada foi realizada antes do início da pandemia de Covid-19 no Brasil, ainda em uma prática pedagógica presencial. Reconhecemos, ainda, que os efeitos da pandemia no contexto escolar estão sendo analisados, sobretudo na relação com as tecnologias digitais e podem acenar com a contribuição dos aspectos que serão desenvolvidos neste texto.

\section{DISCUSSÕES TEÓRICAS}

\subsection{Ensino da língua na cultura digital: a escrita colaborativa}

A leitura e a escrita são atividades construtivas, assim como construídas socialmente. Tratamos aqui com mais ênfase da escrita colaborativa, que se constitui como prática social que tem adquirido cada vez mais espaço na cultura digital. A colaboração, por sua vez, é um processo de produção compartilhada: dois ou mais sujeitos, com habilidades complementares, interagem para criar um conhecimento compartilhado que nenhum deles tinha previamente.

Neste sentido, dialogamos com Silva (2000) considerando que

aprender em um processo colaborativo é planejar, desenvolver ações, receber, selecionar e enviar informações, estabelecer conexões, refletir sobre o processo em desenvolvimento em conjunto com os pares, desenvolver a interaprendizagem, a competência de resolver problemas em grupo e a autonomia em relação à busca e a fazer por si mesmo. (SILVA, 2000, p. 71).

O grupo que trabalha em colaboração é autor e condutor do processo de interação. Cada membro do grupo torna-se também responsável pela própria aprendizagem e co-responsável pelo desenvolvimento dos seus pares. Assim, o professor trabalha junto aos alunos e os incentiva a colaborarem entre si, sendo este, por sua vez, também parte do processo. Os principais objetivos dessa proposta colaborativa centrada no aluno são: a modificação no papel do professor, que passa a ser um facilitador; o desenvolvimento de outras habilidades; e a ampliação da aprendizagem por meio da colaboração. 
Analisando deste modo, em um processo de colaboração, as tecnologias digitais podem auxiliar a escrita num espaço de produção coletiva. Segundo Vygotsky (1998), a aprendizagem inicialmente acontece de forma interpsíquica, ou seja, no coletivo, para depois acontecer a construção intrapsíquica. Na visão do autor, o convívio e as interações sociais são fatores fundamentais para o desenvolvimento cognitivo do indivíduo. Desta forma, entende-se que a escrita colaborativa no âmbito educacional é um fator relevante, visto que tem a possibilidade de alcançar bons resultados, levando em consideração que é um trabalho coletivo. Conforme Shäfer et al. (2009)

as habilidades colaborativas já são uma realidade para o aluno da cultura digital. Ele estabelece redes, cria comunidades e nelas compartilha ideias. Os ambientes descritos são profícuos à autoria em rede: embora não garantam, por si só, o surgimento de uma inteligência coletiva, apresentam condições de possibilidade para o desenvolvimento de tal proposta. (SHÄFER et al., 2009, p. 6).

Sendo assim, pode-se dizer que no processo de escrita colaborativa no meio educacional os sujeitos envolvidos compartilham a aprendizagem, podendo vir a transformar-se individualmente e socialmente.

A Lei de Diretrizes e Bases da Educação Nacional (LDBEN) e a Base Nacional Comum Curricular (BNCC) expressam o consenso de que a função da escola é a formação de um cidadão crítico, ético, livre, participativo e construtor de uma sociedade justa. Para isso, é preciso que haja a garantia de espaços em que os alunos possam pensar livremente. Assim, cabe ao ensino da língua materna possibilitar aos discentes que desenvolvam uma postura crítica mediante os fatos, as interações e os textos, para que estes possam ter autonomia. Desta forma, as atividades pedagógicas referentes ao ensino da Língua Portuguesa devem explorar os mais variados tipos de textos, considerando as diferentes práticas de letramento, e interagindo com a escrita também em práticas sociais.

Para aprofundar a compreensão, faz-se necessário definir o que é um texto especificamente. Muitos falantes entendem que texto é sempre uma ocorrência escrita com várias palavras. Esse entendimento talvez tenha sido herdado da própria cultura escolar, na qual sempre que a palavra texto é mencionada, há a produção de uma redação. Para Koch (2002), o conceito de texto depende do conceito de língua e de sujeito. Conforme a autora:

Na concepção de língua como representação do pensamento e de sujeito como senhor absoluto de suas ações e de seu dizer, o texto é visto como um produto - lógico - do pensamento (representação mental) do autor, nada mais cabendo ao leitor/ouvinte senão captar essa representação mental com as intenções psicológicas do produtor, exercendo, pois, um papel essencialmente passivo. (KOCH, 2002, p. 16).

Assim, essa forma de ver o texto retoma a forma de ver a língua como representação do pensamento, pois é através de frases ordenadas que possibilitamos ao nosso leitor tomar o conhecimento do que pensamos.

A escrita requer mais planejamento do que a fala. Contudo, tanto textos escritos quanto orais exigem cuidados e planejamento por parte do locutor. Quaisquer que sejam as formas e motivações dos sujeitos, as experiências de leitura e escrita podem ser construídas de modo a garantir o desenvolvimento da imaginação, da sensibilidade e do prazer de escrever e ler. Para Costa Val (2006, p. 3) "pode-se definir texto ou discurso como ocorrência linguística, falada ou escrita, de qualquer extensão, dotada de unidade sociocomunicativa, semântica e formal. [...] um texto é uma unidade de linguagem em uso, cumprindo uma função identificável". 
Retomando a visão de Koch (2007, p. 21-22) "o texto é uma sequência de atos da fala; pelas vertentes cognitivas como fenômeno primeiramente psíquico, resultado, portanto, de processos mentais". Assim, o texto é então um conjunto de palavras e frases encadeadas que permitem a interpretação ou transmissão de uma mensagem. Neste sentido, ainda, trazemos a contribuição de Koch (2007), que nos diz que

é preciso pensar a linguagem humana como lugar de interação, de constituição das identidades, de representação de papéis, de negociação de sentidos, portanto, de coenunciação. Em outras palavras, é preciso encarar a linguagem não apenas como representação do mundo e do pensamento ou como instrumento de comunicação, mas sim, acima de tudo, como forma de inter-ação social. (KOCH, 2007, p. 128).

Assim, quando se escreve um texto é preciso haver uma reflexão do contexto e do produto, para que se consiga uma interação com o interlocutor, visto que este é o objetivo principal da comunicação. No contexto da cibercultura e diante das tecnologias digitais, houve a aparição de novos gêneros textuais. Os gêneros textuais ampliaram-se, considerando-se que atualmente a produção de textos diversos não acontece somente na perspectiva educacional. A partir dos anos 1980-1990, os textos passaram a ser o foco de análise para a exploração da leitura e compreensão e para a produção escrita. Contudo, as classificações tipológicas textuais começaram a perder força na medida em que essa abordagem não propiciava uma compreensão crítica dos textos lidos. Já na década de 1990 surgiu a noção dos gêneros textuais como instrumentos de ensino e de aprendizagem, entendidos como algo que amplia a competência comunicativa, tanto na produção quanto na compreensão de textos. Marcuschi (2005) nos diz que

uma simples observação histórica do surgimento dos gêneros revela que, numa primeira fase, povos de cultura essencialmente oral desenvolveram um conjunto limitado de gêneros. Após a invenção da escrita alfabética por volta do século VII a. C., multiplicam-se os gêneros, surgindo os típicos da escrita. Numa terceira fase, a partir do século XV, os gêneros expandem-se com o florescimento da cultura impressa para, na fase intermediária de industrialização iniciada no século XVIII, dar início a uma grande ampliação. Hoje, em plena fase da denominada cultura eletrônica, com o telefone, o gravador, o rádio, a TV e, particularmente, o computador pessoal e sua aplicação mais notável, a internet, presenciamos uma explosão de novos gêneros e novas formas de comunicação, tanto na oralidade como na escrita. (MARCUSCHI, 2005, p. 19).

Desta forma, cabe ressaltar que atualmente vivemos outros tempos, sobretudo demarcados pelas mudanças proporcionadas pela cibercultura. Destarte, Marcushi (2008, p. 198) também indaga se "a escola de amanhã deverá se ocupar de como se produz um email e outros gêneros do discurso do mundo virtual ou se isso não é sua atribuição. Pode a escola continuar ensinando como escrever cartas?". Assim, fica evidente que a escola necessita buscar outras formas de ensinar, para que não fique somente com atividades que se tornem repetitivas e que sejam alinhadas ao cotidiano da vida social.

Frente ao desafio de atender às demandas sociais que se voltam consideravelmente para o uso das tecnologias digitais, a escola mais do que nunca pode se tornar um ambiente que promova práticas pedagógicas e metodologias de ensino que envolvam os alunos em atividades que desenvolvam sua capacidade crítica, para que sejam atuantes na sociedade do conhecimento. Ainda neste sentido, apropriar-se de práticas que contemplem o gênero digital, buscando novos letramentos para uma educação que propicie e valorize o protagonismo dos educandos é fundamental para o ensino contemporâneo, princípios que embasaram a pesquisa aqui apresentada. 


\subsection{Os Memes de Internet como possibilidades de aprendizagem}

É importante perceber que outras linguagens surgiram atualmente com o advento da internet e o surgimento da comunicação digital. No contexto pós-moderno, as práticas discursivas adquirem vários sentidos, e como atualmente a internet influencia nossa cultura, percebe-se uma infinidade de gêneros textuais participando das práticas sociais do cotidiano. Como exemplo, temos o meme, expressão que surgiu em 1976 com a publicação do livro "O Gene Egoísta", de Richard Dawkins. Este estudioso, amparado na teoria darwiniana da evolução natural, criou um pressuposto teórico da memética. Para o autor, assim como o gene, o meme é uma unidade de informação com capacidade de se multiplicar, através das ideias e informações que se propagam de indivíduo para indivíduo. Logo, em tempos de propagação da internet e das redes sociais, temos atualmente o meme de internet, o qual também constitui um gênero textual da atualidade. Conforme Fontanella $(2009$, p.8) os memes, originados de determinados "aspectos sociais, culturais, temporais, espaciais", são percebidos como "ideias, jogos, brincadeiras, piadas ou comportamentos" que se alastram por sua replicação de maneira massiva. Neste contexto, Pretto (1996, p. 106) também nos diz que "outros elementos passam a fazer parte dessa nova linguagem, com a intensificação do uso de símbolos, ícones e imagens. São verdadeiras produções linguísticas que acontecem com outros suportes que não apenas o papel e a caneta".

Ainda neste sentido, a Base Nacional Comum Curricular, no que tange ao ensino da Língua Portuguesa, traz no rol das habilidades referências recorrentes ao ensino da linguagem através dos gêneros digitais, entre estes os memes da internet.

O meme é um texto que traz mensagens a serem interpretadas e que muitas vezes são multiplicadas pelo receptor, tornando-se, assim, uma prática social dos nossos tempos.

Os textos mêmicos carregam em si mensagens que são decodificadas pelos cérebros receptores, analisadas, interpretadas, adotadas e, por vezes, replicadas, tal que, ao se familiarizarem com a linguagem contida no componente a ser replicado, estarão dialogando de certa maneira com o criador do "meme", ou mesmo com os partícipes das mesmas interações de transmissão de ideias. É a linguagem enquanto fenômeno social, como prática de atuação interativa. (SOUZA, 2013, p. 134).

O meme de internet não mostra apenas as características individuais e culturais de quem o cria, mas também de quem o compartilha. Além do mais, é um tipo de texto em sua maioria carregado de humor e ironia, acabando também por influenciar a rede de contatos de quem o compartilha.

As habilidades colaborativas já são realidade para o aluno contemporâneo, que vive imerso na cultura digital. Esse aluno estabelece conexões, cria comunidades, compartilha ideias a todo instante. A escrita colaborativa possui um caráter social, visto que envolve vários sujeitos, com diferentes habilidades, empenhados em um mesmo propósito. Assim, a produção textual com caráter colaborativo, por sua vez, acaba agregando o conhecimento dos vários sujeitos envolvidos na proposta. Da mesma forma, a inclusão de outros gêneros textuais, como o meme, pode tornar-se um elemento que colabore com a produção de textos pelos alunos. Assim, na sequência apresentaremos a experiência de utilização do gênero textual meme nas práticas pedagógicas da disciplina de Produção Textual. 


\section{A CONSTRUÇÃO METODOLÓGICA DA PESQUISA-INTERVENÇÃO}

Em contraposição às aulas da disciplina de Produção Textual realizadas somente com o uso do caderno e lousa, propusemos uma atividade que fosse além do tradicional já vivenciado pelos alunos. A atividade realizada com as tecnologias digitais demandava que os alunos interagissem com seus pares, assumindo assim um papel ativo e colaborativo frente à sua aprendizagem. Neste sentido, Marcon (2015, p. 34) afirma que "atualmente o sujeito sente-se capaz de participar, interagir, produzir e distribuir conteúdos, principalmente porque reconhece o potencial comunicativo que é inerente à rede, assim como outras características como a cooperação e participação". A atividade foi considerada interativa porque os celulares, com acesso à internet, eram ferramentas indispensáveis nesse processo. Da mesma forma, a tarefa demandava interação entre os usuários, já que o desenvolvimento da atividade proposta deveria ser realizado em grupo.

Para realizar a atividade proposta, os alunos escolheram e utilizaram um aplicativo gratuito disponibilizado na loja de aplicativos de seus celulares, para a produção de memes. A escola em que foi realizada a pesquisa-intervenção está localizada em um município pequeno, ao Sul do Brasil, na fronteira com o Uruguai. Na instituição existia o componente curricular de Produção Textual para os anos finais do Ensino Fundamental, disciplina que compõe a parte diversificada da grade curricular. A disciplina de Produção Textual é uma das aulas que muitos dos alunos não têm apreço, principalmente porque muitos destes encontram considerável dificuldade, ficando por vezes desinteressados na realização de tal atividade ou porque o direcionamento da atividade acaba sendo exaustivo ou repetitivo. O processo de escrita, por sua vez, demanda bastante atenção aos critérios fundamentais da elaboração de um texto, para que esteja coeso e coerente, sendo necessário cuidado e atenção a sua estrutura.

A proposta partiu ou teve como referência um meme, que em alguns encontros foram pesquisados na internet e em outros foram produzidos pelos alunos, sendo que deveriam estar de acordo com o tema proposto. Os assuntos tratados nas produções textuais foram: educação, saúde, segurança pública, redes sociais, escola e avaliação na escola e tecnologias digitais. Estes temas foram escolhidos por serem de interesse dos alunos escreverem sobre eles, terem relevância social e também para perceber um pouco da visão crítica do público jovem a respeito destes temas. A turma foi organizada em grupos de cinco alunos. Os próprios discentes tiveram a oportunidade de se organizarem nos grupos. A proposta era que cada grupo elaborasse um meme diferente dos outros grupos, juntamente com a produção textual.

A atividade desenvolveu-se em oito encontros, com duração de uma hora e trinta minutos cada um. No início de cada encontro os alunos organizavam-se nos seus grupos, para após produzirem os memes e realizarem a produção textual, de acordo com o tema de cada encontro.

Para analisar os dados coletados na pesquisa-intervenção foram utilizados o diário de campo, a observação-participante e a análise documental. Houve bastante proximidade com os estudantes, tanto para pesquisá-los como para auxiliá-los na atividade proposta. O diário de campo, onde foram registradas as observações, serviu de fonte para registrar todas as situações realizadas, embora descritas de forma simples, atentando para os detalhes que se apresentavam no decorrer da proposta. Outro documento que serviu para analisar a intervenção foram as produções textuais dos alunos e seus relatos sobre a pesquisa-intervenção, compondo assim uma análise documental. Assim, apresentaremos, na sequência, a discussão dos resultados tendo como enfoque a análise dos memes. 


\section{DISCUSSÃO DOS RESULTADOS}

Atualmente, com a propagação da internet e seu alcance na palma das nossas mãos, nos transformamos em escritores e leitores ubíquos, ou seja, ao passo que nos deslocamos nos comunicamos, exercendo a "habilidade de comunicação a qualquer hora e tempo, por meio dos dispositivos móveis" (SANTOS, 2013, p.289). Desta forma, a nossa atividade de ler, escrever e nos comunicarmos alcançou os mais variados espaços, bastando para isso somente um dispositivo móvel. Dialogamos com Santaella (2013, p. 53) quando nos diz que "os dispositivos móveis serão cada vez mais poderosos nos aspectos de usabilidade". Desta forma, no tempo em que vivemos, já é possível perceber as suas mais diversificadas possibilidades de uso. As intervenções realizadas na turma demonstraram uma dessas possibilidades, no que tange à área educacional, tendo em vista que os alunos tiveram a possibilidade de utilizar o smartphone para outra finalidade, diferente da que estavam habituados, contribuindo para o processo de ensino e de aprendizagem.

Um dos objetivos específicos da pesquisa-intervenção foi proporcionar aos alunos outras formas de produzirem textos, que saísse do uso tradicional do papel e da caneta e se vinculasse ao mundo digital, tendo em vista que o público-alvo envolvido na pesquisa-intervenção possuía acesso às tecnologias digitais e em muitas aulas apresentava resistência às atividades de escrita de textos. Desta forma, utilizar outras metodologias de ensino e de aprendizagem tornou-se uma tarefa fundamental no mundo contemporâneo, tendo em vista que o conhecimento está em todos os lugares, num simples toque de tela. Neste sentido, Santos (2014, p. 48) nos diz que "Aprendemos por toda a parte. Essa potencialidade comunicacional não substitui as aprendizagens mediadas formalmente pelas instituições educacionais. Muito pelo contrário. Pode potencializá-las".

Em todos os encontros os alunos apresentaram-se extremamente ativos na participação da atividade, tanto na elaboração do meme quanto na realização da produção textual. Os próprios alunos, a partir do segundo encontro, já apresentaram autonomia tanto para a organização dos grupos como para a realização da tarefa. Isso é um fator relevante a ser considerado quando se trabalha com os aplicativos móveis como ferramentas de ensino e de aprendizagem ou com atividades que sejam de interesse dos educandos.

Assim, percebemos que houve uma potencialização comunicacional com a intervenção pedagógica, ao passo que os alunos ao mesmo tempo em que demonstraram interesse pela atividade, aumentaram seu potencial em relação à escrita. Considerando que, dos estudantes envolvidos na pesquisa-intervenção, com exceção de um grupo analisado, todos os outros evoluíram no processo de escrita, levando em consideração a organização do texto e a coesão e coerência referentes ao assunto abordado.

Não é difícil constatar que nos últimos tempos foram as tecnologias digitais, em especial as ligadas à área da comunicação, que propiciaram o surgimento de novos gêneros textuais. Destarte, a intensidade dos usos dessas tecnologias e suas interferências nas atividades comunicativas diárias fazem com que isso aconteça. Assim, trabalhar também com a produção textual associada aos memes, considerando-o um gênero textual digital da contemporaneidade, foi algo inédito na turma participante da pesquisa-intervenção. Da mesma forma que alguns docentes solicitam aos seus alunos desenharem uma imagem para relacionarem ao texto, agimos de maneira semelhante, contudo utilizando um aplicativo que tem a possibilidade de integrar linguagem verbal e visual para tal associação, não se limitando a uma mera ilustração, e sim produzindo uma interpretação e expressão específicas sobre o tema em questão, com alto potencial comunicacional. Conforme 
Santaella (2013, p. 266) "o ato de ler passou a não se limitar apenas a decifração de letras, mas veio também incorporando cada vez mais, as relações entre palavras e imagens, entre o texto, a foto e a legenda, entre o tamanho dos tipos gráficos e o desenho da página, entre o texto e a diagramação".

Os memes atualmente são uma característica marcante na internet. Qualquer acontecimento é passível de se transformar em meme, envolvendo os mais variados assuntos. Eles transmitem a mensagem de maneira humorada e ganham repercussão porque se disseminam com facilidade. $\mathrm{Na}$ maioria das vezes são produzidos pelos jovens, que têm considerável habilidade nessa produção. Os memes produzidos pelos alunos participantes da pesquisa-intervenção evidenciaram essa facilidade que os adolescentes têm em relação ao uso dos aplicativos digitais e suas funcionalidades. Neste sentido, a escrita unida à imagem se coloca diante de nossos olhos diariamente, e mais presente ainda frente ao uso das tecnologias digitais. Conforme Oliveira (2019) o meme

além de oferecer uma multiplicidade de temas apresentados de forma humorística, lúdica e, muitas vezes, crítica e irônica, esse novo gênero possui tanto um caráter contínuo quanto efêmero e pode ser produzido ou recriado por qualquer usuário a partir de uma imagem, uma cena ou uma frase. (OLIVEIRA, 2019, p. 224).

Desde o primeiro encontro com a turma percebemos que todos tinham conhecimento do gênero textual meme e mesmo que alguns alunos não o produzissem através de aplicativos digitais, conheciam os memes e poderiam tanto pesquisá-los quanto elaborá-los, desde que mediados por mim ou por outro colega que tivesse maior habilidade. Logo, foi o que aconteceu durante todos os encontros realizados na turma com a maioria dos grupos envolvidos.

Figura 1: Meme elaborado pelo Grupo 4

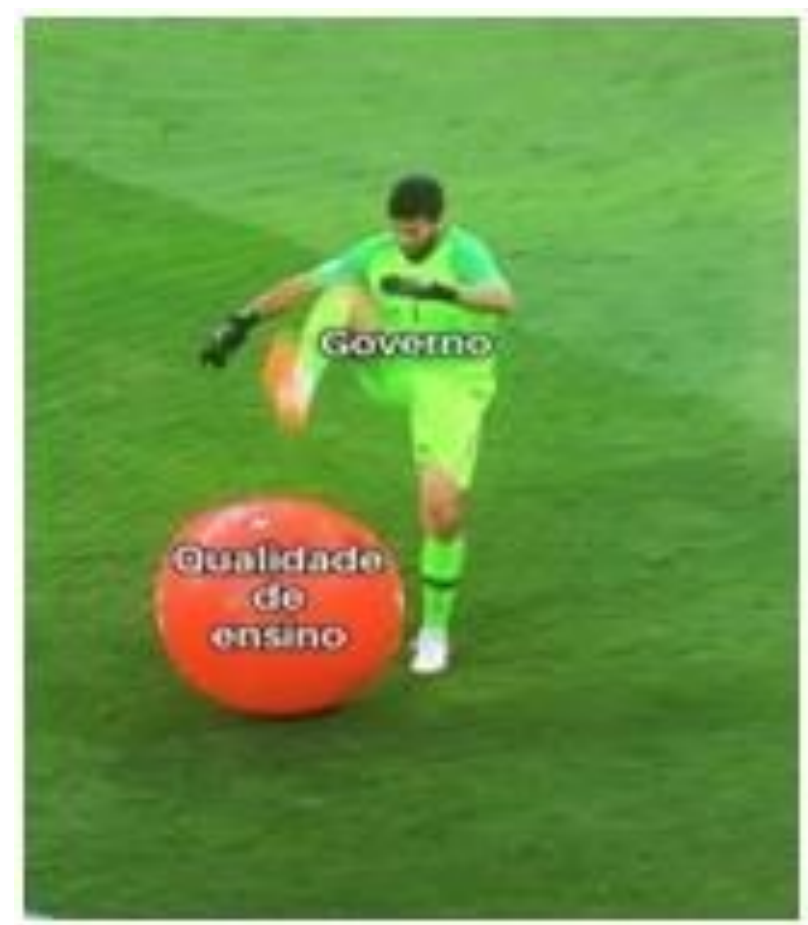

Fonte: Reprodução de meme produzido pelo Grupo 4. 
Figura 2: Meme elaborado pelo Grupo 2

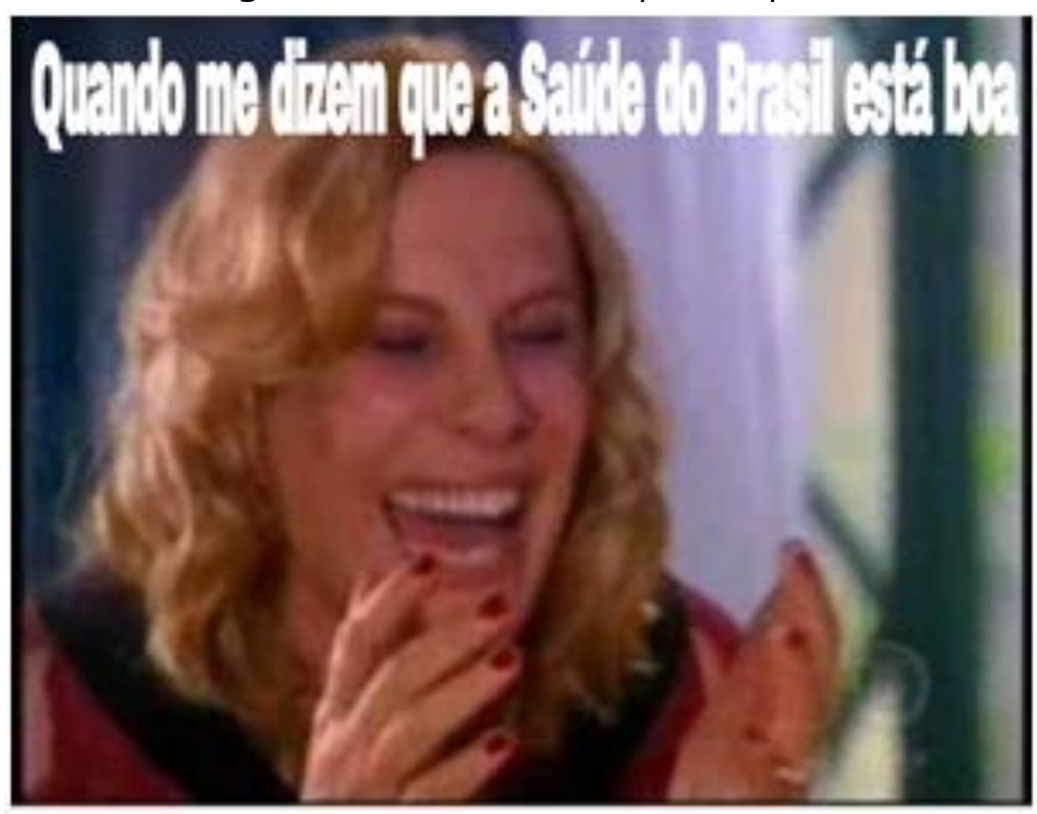

Fonte: Reprodução de meme produzido pelos Grupo 2.

Os alunos participantes da pesquisa-intervenção foram consideravelmente ativos na produção dos memes, a fim de os relacionarem com os textos produzidos. Para realizarem esta tarefa não necessitaram de grande estímulo. Esse fato evidencia, por sua vez, que esse grupo de alunos já percebe a associação de linguagem verbal e visual, num contexto digital, como algo "natural", que faz parte do seu cotidiano.

Os memes produzidos pelos alunos, além de mostrarem a criatividade na elaboração ou pesquisa, evidenciaram a estreita relação que fizeram com o assunto abordado na produção textual, deixando exposto assim a capacidade de agregar imagem e texto de forma coesa e organizada, em situações cotidianas do processo de ensino e de aprendizagem. Também foi possível evidenciar a capacidade crítica e comunicacional das produções de memes, no alinhamento da produção de texto aos princípios da cibercultura, sobretudo a colaboração, autoria e interatividade.

\section{CONSIDERAÇÕES FINAIS}

O ensino na sociedade contemporânea exige dos docentes também outros saberes que não mais somente aqueles adquiridos na época de sua formação inicial. A sociedade do conhecimento hoje perpassa por inúmeras transformações em curto prazo, fazendo com que tenhamos que estar sempre em constante aprendizado para acompanhar essa evolução. Propiciar atividades que possibilitem o uso das tecnologias digitais no ensino necessita fazer parte da cultura escolar, considerando que pertencemos à sociedade do conhecimento. Assim, sendo a escola o principal agente transformador da sociedade, é de grande relevância que ela se adapte também às mudanças que o mundo contemporâneo atravessa, e que de certa forma impõem, tendo em vista que os alunos diariamente têm a possibilidade de construir conhecimento não mais somente dentro dos muros da escola. Já não basta que nos detenhamos unicamente a metodologias que parecem não apresentar resultados satisfatórios para atender a demanda do ensino atualmente. O aluno da sociedade do conhecimento, que está habituado ao contato com a internet, exige do docente habilidade para atuar em tempos de cibercultura. É possível perceber que os alunos já reconhecem essa lacuna que existe em muitas 
escolas atualmente em relação aos usos das tecnologias digitais e compreendem que elas podem proporcionar melhores resultados na aprendizagem.

Um dos objetivos da pesquisa pautou-se em proporcionar uma atividade de produção textual com mais ânimo por parte dos discentes, tendo em vista que tal atividade às vezes é motivo de falta de interesse nos alunos dessa faixa etária do público envolvido na pesquisa. Refletindo acerca disso pudemos constatar que proporcionar uma atividade que envolvesse os seus dispositivos móveis, aparelhos que os acompanham diariamente, foi também um fator relevante para concretizar com êxito a pesquisa. Desta forma, percebemos que o uso desses dispositivos proporcionou uma aproximação maior dos alunos com a disciplina de Produção Textual.

Também é importante destacar que o trabalho envolvendo o gênero textual meme destacou a criatividade dos sujeitos pesquisados, tendo em vista que estes tiveram a possibilidade de usar a imaginação para criar algo que pudesse ser relacionado com o tema escolhido para a produção textual a ser elaborada. Desta forma, estando nós situados em um contexto digital, que faz parte nossas atividades cotidianas, é urgente que as escolas se aliem também aos processos de ensino e de aprendizagem que contemplem a utilização de recursos digitais, a fim de não ficarem obsoletas ao passo de não conseguirem atender a demanda de alunos conectada que hoje compõem as salas de aulas.

\section{REFERÊNCIAS}

BRASIL. Ministério da Educação. Base Nacional Comum Curricular. Brasília, 2018.

BRASIL. Lei de Diretrizes e Bases da Educação Nacional. LDBEN. 9394/1996. BRASIL, 1996.

COSTA VAL, Maria da Graça. Redação e Textualidade. São Paulo: Martins Fontes, 2006.

FONTANELLA, Fernando. 0 que é um meme na Internet? Proposta para uma problemática da memesfera. Trabalho apresentado no III Simpósio Nacional da ABCiber, São Paulo, 2009.

KOCH, Ingedore Grunfeld Villaça. $O$ texto e a construção dos sentidos. 9a Ed. São Paulo: Contexto, 2007.

LÉVY, Pierre. Cibercultura. São Paulo. Ed. 34. 1999.

MARCON, Karina. A inclusão digital na formação inicial de educadores a distância: estudo de multicaso nas univeridades abertas do Brasil e de Portugal. Tese (doutorado)- UFRGS, 2015

MARCUSCHI, Luis Antônio. Gêneros textuais emergentes no contexto da tecnologia digital. In: MARCUSCHI, L. A. \& XAVIER, A. C. (Orgs.) Hipertexto e gêneros digitais. Rio de Janeiro: Editora Lucerna, 2004.

OLIVEIRA, Ariosvalber de Souza. Notas sobre inclusão digital no espaço escolar à luz dos usos dos memes. Revista Periferia, v. 11, n. 1, p. 214-230, jan./abr. 2019

PRETTO, Nelson de Luca. ASSIS, Alessandra. Cultura digital e educação: redes já! In PRETTO, NL., and SILVEIRA, SA., orgs. Além das redes de colaboração: internet, diversidade cultural e tecnologias do poder. [online]. Salvador: EDUFBA, 2008. pp. 75-83. ISBN 978-85-2320-889-9.

SANTAELLA, Lúcia. Comunicação Ubíqua: repercussões na cultura e na educação. São Paulo. Paulus, 2013 
SANTOS, Edméa Oliveira. Educação e cibercultura: aprendizagem ubíqua no currículo da disciplina didática. Revista Diálogo Educacional, Curitiba, v. 13, n. 38, p. 285-302, jan./abr. 2013.

SANTOS, Edméa Oliveira. Pesquisa-formação na Cibercultura. Santo Tirso. Portugal: Whitebooks, 2014.

SCHÄFER, Patrícia Behling. LACERDA, Rosália. FAGUNDES, Léa da Cruz. Escrita colaborativa na cultura digital: ferramentas e possibilidades de construção do conhecimento em rede. Revista Renote: Novas Tecnologias e Educação. Universidade Federal do Rio Grande do Sulhttp://www.seer.ufrgs.br/index.php/renote/article/view/14012/7902

SIBÍLIA, Paula. Redes ou Paredes: A escola em tempos de dispersão. Rio de Janeiro. Contraponto, 2012.

SILVA, Marco. Sala de aula interativa. Rio de Janeiro: Quarteto, 2003.

SILVA, Marco. Sala de aula interativa: A educação presencial e à distância em sintonia com a era digital e com a cidadania. XXIV Congresso Brasileiro da Comunicação - Campo Grande /MS setembro 2001.

SOUZA, Carlos Fabiano de. Memes: formações discursivas que ecoam no ciberespaço. Vértices, Campos dos Goytacazes, v. 15, n. 1, p. 127-148, janeiro a abril de 2013.

VYGOTSKY, Lev. A formação social da mente: o desenvolvimento dos processos psicológicos superiores. 6ª Ed. São Paulo: Martins Fontes, 1998.

Submissão: 27/03/2021

Aceito: 05/05/2021 